\title{
Collaboration Networks and Document Networks in Informetrics Research from 2001 to 2011: Finding Influential Nations, Institutions, Documents*
}

\author{
계량정보학분야의 협력연구 네트워크 및 문헌네트워크 분석 : \\ 국가, 기관, 문헌단위 분석 \\ Jae Yun Lee (이재윤)** \\ Sanghee Choi (최상희)***
}

\begin{abstract}
Since information scientists have begun trying to quantify significant research trends in scientific publications, '-metrics' research such as 'bibliometrics', 'scientometrics', 'informetrics', 'webometrics', and 'citation analysis' have been identified as crucial areas of information science. To illustrate the dynamic research activities in these areas, this study investigated the major contributors of '-metrics' research for the last decade at three levels: nations, institutions, and documents. '-metrics' literature of this study was obtained from the Science Citation Index for the years 2001-2011. In this analysis, we used Pathfinder network, PNNC algorithm, PageRank and several indicators based on h-index. In terms of international collaborations, USA and England were identified as major countries. At the institutional level, Katholieke University, Leuven and the University of Amsterdam in Europe and Indiana University and the Office of Naval Research in the USA have led co-research projects in informetrics areas. At the document level, Hirsch's h-index paper and Ingwersen's web impact factor paper were identified as the most influential work by two methods: PageRank and single paper h-index.
\end{abstract}

\section{초 록}

계량정보학자들이 학술논문을 통해 과학 연구 동향을 분석하기 시작한 이후 계량서지학, 과학계량학, 계량정보학, 웹계량학, 인용분석 등은 정보학의 주요 분야로 성장하였다. 계량정보학의 최근 동향을 분석하기 위하여 이 연구에서는 계량정보학 연구출판물을 기반으로 하여 이 분야 연구 발전에 기여한 국가, 기관, 논문을 파악하고자 네트워크 분석을 수행하였다. 데이터 수집을 위해서는 SCI 데이터베이스를 이용하였으며 2001년부터 2011년까지 출판된 논문을 대상으로 하였다. 분석기법으로 Pathfinder 네트워크 분석과 PNNC기법을 사용하고, 협력관계와 연구영향도를 측정하기 위한 지표로 PageRank와 h-index 기반의 지표들을 사용하였다. 협력연구네트워크에서 주요한 역할을 하는 국가는 미국과 영국인 것으로 조사되었으며 기관으로는 유럽의 암스테르담 대학과 루벤 카톨릭대학 그리고 미국의 인디아나 대학과 해군연구개발국이 기여를 하고 있는 것으로 나타났다. 개인 논문 수준에서는 PageRank와 single paper h-index 척도로 분석한 결과 Hirsch의 h-index 논문과 Ingwersen의 웹 영향력 지수 논문이 가장 영향력 있는 것으로 조사되었다.

Keywords: informetrics, intellectual structure, network analysis, collaboration network, document network

계량정보학, 지적구조, 네트워크 분석, 협력네트워크, 문헌네트워크

* This paper is a revised version of 8th International Conference on WIS \& 13th COLLNET Meeting presentation.

** Myongji University, Department of Library \& Information Science(memexlee@mju.ac.kr) (제1저자) *** Catholic University of Daegu, Department of Library Science(shchoi@cu.ac.kr) (교신저자)

- 논문접수일자 : 2013년 2월 20일 - 최초심사일자 : 2013년 2월 27일 - 게재확정일자 : 2013년 3월 16일

- 정보관리학회지, 30(1), 179-191, 2013. 〔http://dx.doi.org/10.3743/KOSIM.2013.30.1.179〕 


\section{Introduction}

Bibliometrics is defined as a quantitative analysis of scientific publications for the purpose of revealing specific patterns. Cattel's analysis of a biographical directory of American scientists in early 1900's captured the attention of many information scientists who were interested in tracing research activities via bibiliographic data. Since this groundbreaking work, numerous aspects of the major concepts of bibliometrics have been explored.

Scientometrics is typically defined as the 'quantitative study of science and technology' (Hood \& Wilson, 2001). According to Brookes (1990), scientometrics is particularly useful in science policy studies.

Informetrics, the most recent concept within the field, was proposed by Nacke to cover the area of information science that measures information phenomena (Hood \& Wilson, 2001). Informetric studies apply mathematical methods to questions involving bibliometrics and information retrieval theory. However, as abroad concept the term can be applied to bibliometrics and scientometrics as well. Brookes (1990) noted that informetrics is a general term for bibliometrics and scientometrics, even though scientometrics generally refers to policy studies and bibliometrics is connected more to library studies.

Webometrics, a subfield of informetrics often called 'cybermetrics' or 'link analysis', is one of the new trends in informetrics that applies informetric analysis to Web publications.

Citation analysis was introduced to information scientists before the above areas emerged. Its formation began when Eugene Garfield (1955) compiled 'an association of ideas index' from a large-scale study of citation relationships. Based on Garfield's study, the Science Citation Index (SCI), to date the most influential source for citation analysis research, was developed. Wouters (1999) describes the SCI as the start of citation culture. Through the years it has also been used as a primary resource for bibliometrics, scientometrics, and informetrics research.

These areas have been central to leading '-metrics' research since 2001. In the preliminary study, we examined the productivity of leading countries and researchers to illustrate intellectual structure in these areas since 2001 (Lee \& Choi, 2011). Due to the growth and increased diversity of '-metrics' research, it is important to review the contributors to the development of these areas and to identify how they have collaborated in depth. We expanded the previous study to provide an overall view of informetrics research.

\section{Purpose of the Study}

'Bibliometrics', 'scientometrics', 'informetrics', 'webometrics', and 'citation analysis' embrace quantitative concepts; however, 'informetrics' refers to all of these areas. This study aims to illustrate the dynamic progress of informetrics using statistical and profiling methods. We explored informetrics research at three levels: 1) nations, 2) institutions, and 3) documents. First we identified the major countries in informetrics research as well as the collaboration 
networks that link them, in order to determine the contribution of each country. Second, we investigated these leading institutions to discover the purpose or motivation behind notable informetrics research. Third, we found out the core informetrics publications according to various criteria, to find out which documents have had the greatest impact on informetrics researchers. We also analyzed co-citation networks among influential papers to identify significant topics within informetrics research.

\section{Methods and Data}

Three informetrics methods were independently used in three stages. In the first stage, a statistical examination of informetrics articles found via a search of the citation index database Web of Science was conducted to identify the productivity of each country and institution. Data were collected through a search of the Web of Science. The time span was limited to 2001-2011. This search was executed on May 21, 2011. The submitted search query was as follows:

[Query : TOPIC $=($ citation analysis OR bibliometrics OR informetrics OR scientomerics OR webometrics) refined by Document Type= (ARTICLE OR PROCEEDINGS PAPER OR REVIEW) Timespan=2001-2011. Databases= SCI-EXPANDED, SSCI, A\&HCI]

In the second stage, collaboration structures for informetrics were derived using the bibliographic data of co-published documents. The centralities of nations and institutions were also calculated, using Pajek (de Nooy, Mrvar, and Batagelj, 2011), in order to identify the major contributors. In addition, a collaboration h-index (col-h-index) and a collaboration hs-index (col-hs-index) were used to derive a status scale, by country, of informetrics research projects. Collaboration h-index, which was developed for collaboration research analysis (Lee, 2010), is an application of Hirsh's h-index. Collaboration hs-index is based on the hs-index, which was proposed by Lee (2006a) to compensate for the low discrimination power of Hirsch's h-index. A country has col-h if it collaborated with other countries at least $\mathrm{h}$ times each, and the other countries collaborated with that country no more than $\mathrm{h}$ times each. To calculate the collaboration hs-index, we took the square roots of each numbers of collaborations within the h-ranking, and summed the resulting numbers.

In the third and final stage, we used several document-level measures such as cited frequency, PageRank (Brin \& Page, 1998) and single paper h-index (Schubert, 2009) to determine the citation impact of a particular scientific publication. In addition we analyzed the co-citation network of 158 core documents and graphed our results using a Pathfinder network. We also identified major clusters using a PNNC (parallel nearest neighbor clustering) algorithm (Lee, 2006b; Kim \& Lee, 2008) to discover the main research themes since 2001. The PNNC algorithm is useful for domain analysis because the resulting cluster numbers are decided automatically and the cluster structure itself is consistent with results 
found via a Pathfinder network (Kim \& Lee, 2008). In this study, the Pathfinder network and PNNC algorithms were conducted using WNET version 0.4 (Lee, 2011b), a Python application.

\section{Findings and Discussions}

\subsection{Research output and impact at the national level}

At the national level of research collaboration, the USA and England achieved dominant positions by two important criteria: the number of partner countries and the intensity of collaborations. These leading countries collaborated actively with various other countries (figure 1). To analyze each country's status in depth, we calculated the collaboration centralities of 32 countries using Pajek.

Two applications of Hirsch type indices were calculated to satisfy the above criteria. Collaboration h-index (col-h) and collaboration hs-index (col-hs) were used to show the range of national collaboration (the number of countries that had collaborated with one particular country) and the intensity of collaboration (expressed as the number of collaborations).

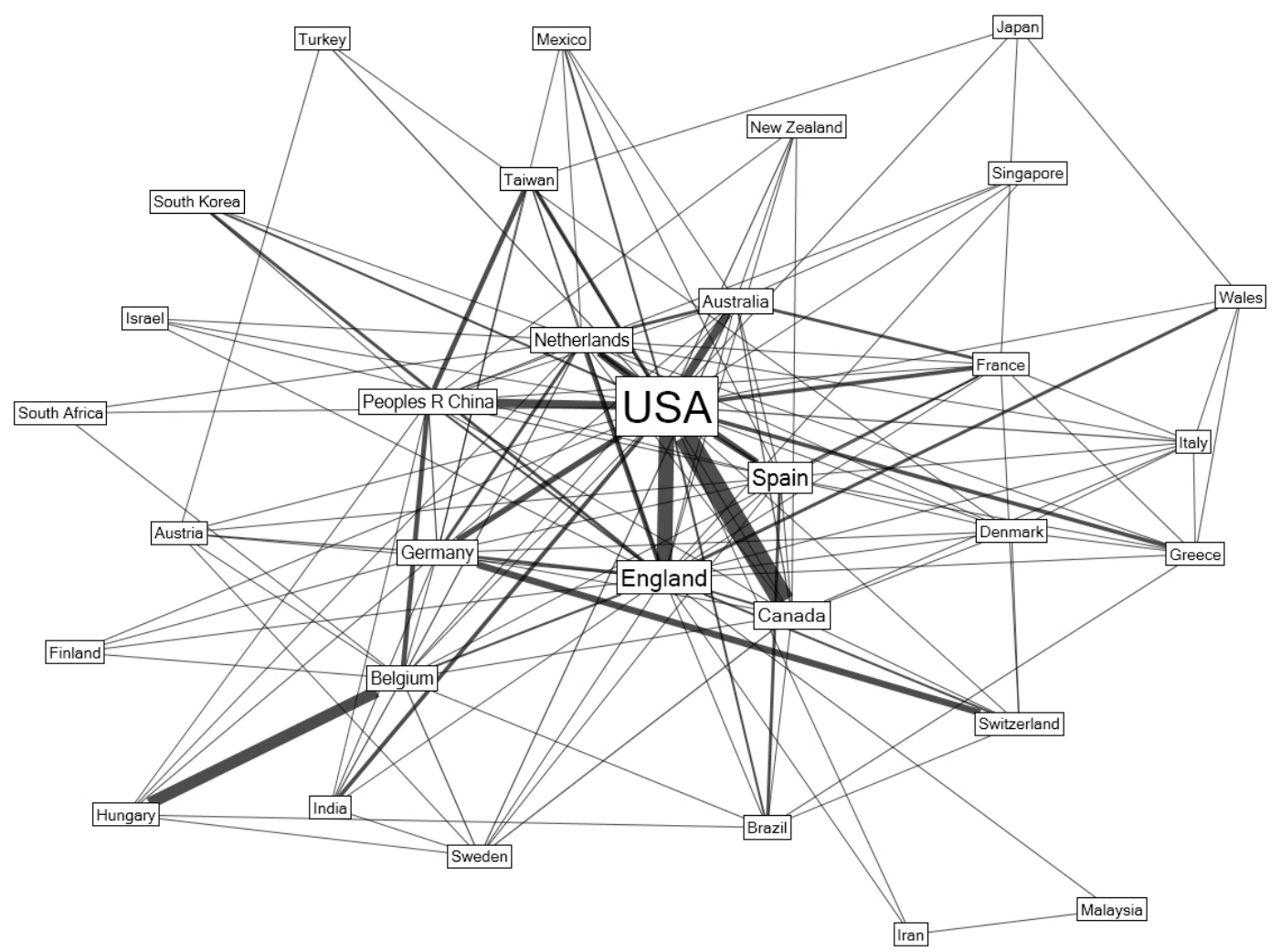

〈Figure 1〉 Research collaboration networks at the national level 
$\langle$ Table 1〉 Country centrality and collaboration indices in the collaboration network

\begin{tabular}{l|c|c|c|c|c}
\hline \multicolumn{1}{c|}{ Country } & Degree & Closeness & Betweenness & Col-h-index & Col-hs-index \\
\hline USA & $28\left(1^{*}\right)$ & $0.9118(1)$ & $0.2607(1)$ & $6(1)$ & $21.85(1)$ \\
\hline England & $26(2)$ & $0.8611(2)$ & $0.2065(2)$ & $5(2)$ & $13.71(2)$ \\
\hline Netherlands & $18(3)$ & $0.7045(3)$ & $0.0574(3)$ & $5(2)$ & $12.59(3)$ \\
\hline Germany & $16(4)$ & $0.6739(4)$ & $0.0365(4)$ & $4(4)$ & $10.30(5)$ \\
\hline Spain & $16(4)$ & $0.6739(4)$ & $0.0308(6)$ & $4(4)$ & $9.33(6)$ \\
\hline Canada & $15(6)$ & $0.6596(6)$ & $0.0221(8)$ & $3(7)$ & $8.93(7)$ \\
\hline Belgium & $15(6)$ & $0.6596(6)$ & $0.0349(5)$ & $3(7)$ & $8.52(8)$ \\
\hline Peoples R China & $15(6)$ & $0.6596(6)$ & $0.0307(7)$ & $4(4)$ & $10.61(4)$ \\
\hline Australia & $13(9)$ & $0.6327(9)$ & $0.0166(9)$ & $3(7)$ & $7.79(9)$ \\
\hline France & $11(10)$ & $0.6078(10)$ & $0.0147(10)$ & $3(7)$ & $6.69(10)$ \\
\hline
\end{tabular}

* Numbers in parentheses are rank

In these indices, the highly ranked countries have conducted many research projects with a variety of other countries. The countries that have collaborated with fewer other countries, as well as the countries that only collaborated with others a few times, are ranked lower in both the col-h-index and col-hs-index.

The U.S. tops all the lists according to five evaluating factors: degree, closeness, betweenness, col-h-in dex, and col-h-index. With few exceptions, the same 10 countries appeared on the top of the list, in the same order.

China was more highly ranked by col-h-index and col-hs-index than by centralities criteria. China also seemed to collaborate actively with multiple countries but attained lower status within the research collaboration network. China seemed to be an emerging country in informetrics domain of last decade. China's strong partnership with few selected countries, USA and Belgium, resulted in a noticeable increase of research outcomes in this area.

The status of Belgium by betweenness was slightly different than its status according to the other two measures. Belgium had conducted many research projects with not only major contributors such as European countries and the USA but also with nations all over the world including South Africa, Brazil, India, and China. Therefore, in the collaboration network Belgium ranked higher by betweenness $\left(5^{\text {th }}\right)$ than by degree and closeness $\left(6^{\text {th }}\right)$.

\subsection{Research output and impact at the institutional level}

According to figure 2, Katholieke University Leuven and the University of Amsterdam in Europe and Indiana University and the Office of Naval Research in the USA have played key roles in co-research projects involving informetrics.

Table 2 shows the centralities and collaboration indices of 26 institutions that collaborated with more than three other institutions. Because Katholieke University Leuven worked with most institutions and the number of its collaborative research projects was relatively high, its collaboration indices rank at second place. In Europe, University of Amsterdam was 


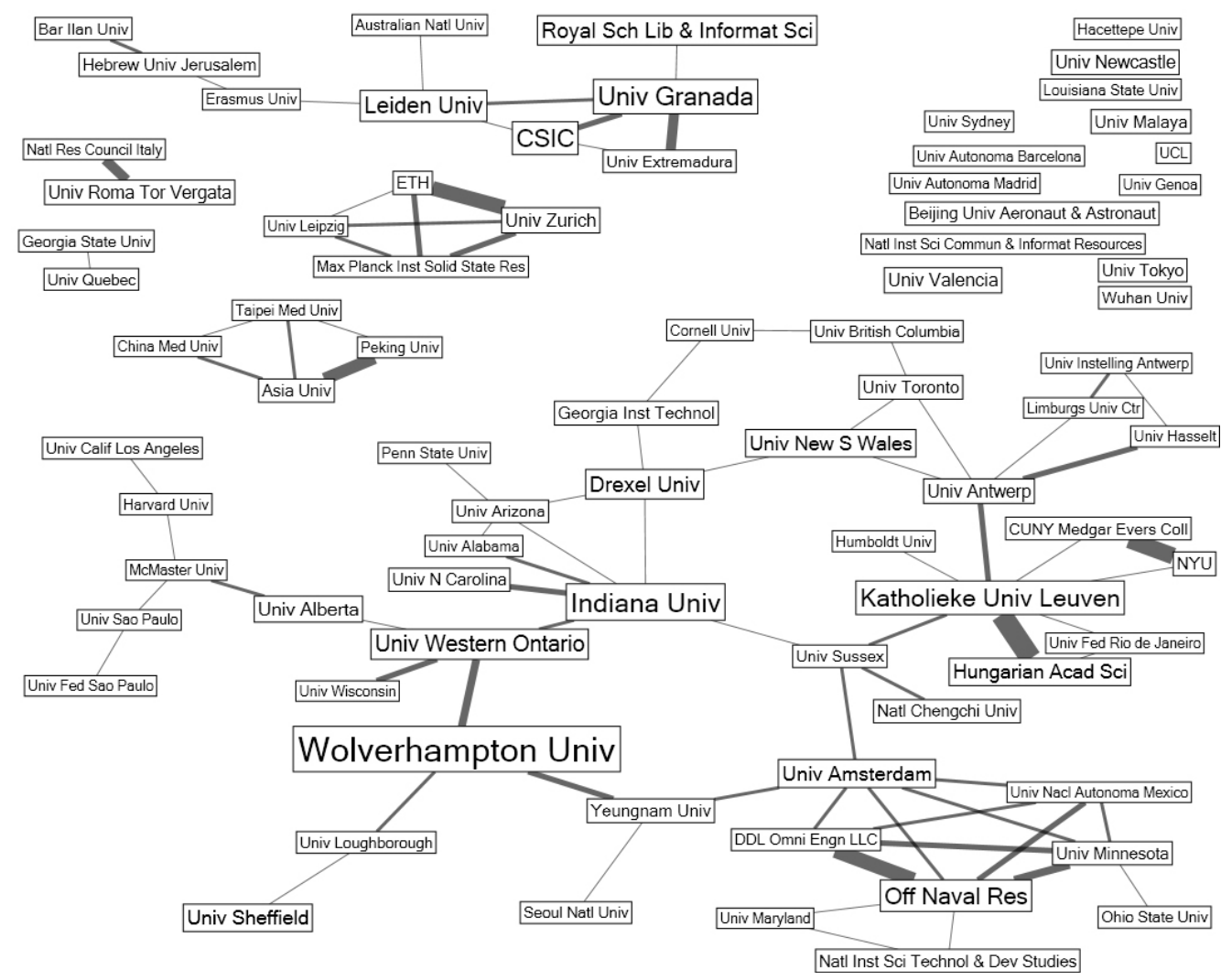

〈Figure 2〉 Research collaboration network at the institutional level

$\langle$ Table 2〉 Institutional centralities and collaboration indices within the collaboration network

\begin{tabular}{l|l|l|l|l|c|c}
\hline \multicolumn{1}{c|}{ Institution } & \multicolumn{1}{c|}{ Country } & Degree & Closeness & Betweenness & Col-h-index & Col-hs-index \\
\hline Katholieke Univ. Leuven & Belgium & $7\left(1^{*}\right)$ & $0.2094(3)$ & $0.1513(5)$ & $2(2)$ & $5.20(2)$ \\
\hline Indiana Univ. & USA & $6(2)$ & $0.2347(2)$ & $0.1969(2)$ & $2(2)$ & $3.15(14)$ \\
\hline Univ. Amsterdam & Netherlands & $6(2)$ & $0.2079(4)$ & $0.1515(4)$ & $2(2)$ & $2.83(17)$ \\
\hline Off Naval Res & USA & $6(2)$ & $0.1673(15)$ & $0.0407(12)$ & $3(1)$ & $6.38(1)$ \\
\hline Univ. Antwerp & Belgium & $5(5)$ & $0.1808(10)$ & $0.0894(7)$ & $2(2)$ & $3.46(11)$ \\
\hline Univ. Minnesota & USA & $5(5)$ & $0.1663(17)$ & $0.0208(15)$ & $2(2)$ & $3.73(8)$ \\
\hline Univ. Sussex & England & $4(7)$ & $0.2386(1)$ & $0.2017(1)$ & $2(2)$ & $2.83(17)$ \\
\hline Univ. Western Ontario & Canada & $4(7)$ & $0.2050(5)$ & $0.1586(3)$ & $2(2)$ & $3.73(8)$ \\
\hline Drexel Univ. & USA & $4(7)$ & $0.1994(6)$ & $0.0779(9)$ & $1(19)$ & $1.00(42)$ \\
\hline Univ. Arizona & USA & $4(7)$ & $0.1902(7)$ & $0.0230(14)$ & $1(19)$ & $1.00(42)$ \\
\hline Leiden Univ. & Netherlands & $4(7)$ & $0.0852(45)$ & $0.0094(23)$ & $1(19)$ & $1.41(30)$ \\
\hline Univ. Granada & Spain & $4(7)$ & $0.0738(46)$ & $0.0047(27)$ & $2(2)$ & $3.97(6)$ \\
\hline DDL Omni Engn LLC & USA & $4(7)$ & $0.1654(18)$ & $0.0000(33)$ & $2(2)$ & $4.38(3)$ \\
\hline Univ. Nacl Autonoma Mexico & Mexico & $4(7)$ & $0.1654(18)$ & $0.0000(33)$ & $2(2)$ & $3.15(14)$ \\
\hline
\end{tabular}

* Numbers in parentheses are rank 
ranked on the second influential institution according to the degree of collaboration.

A closer look at the collaboration structure gives an interesting point to discuss. In terms of closeness and betweenness, the University of Sussex was top-ranked. It connected multiple European institutions with USA institutions. The University of Sussex and University of New South Waleswere recognized as bridges between major research institutions in two continents, Europe and America. Interestingly, both institutions are universities in UK.

Some institutions showed inverse performance in terms of centrality and h-index criteria. Indiana University was in second place according to all three centrality criteria, but according to the col-hs-index it placed $14^{\text {th }}$. This discrepancy means that Indiana University collaborated with many institutions, but the number of collaborations per institution was only one or two.

Drexel University and University of Arizona also showed similar tendency in this network. They placed notably higher by degree, closeness, and betweenness than the col-h-index and the col-hs-index.

By contrast, the U.S. Office of Naval Research is at the top of both collaboration indices. Its global collaborative status, which is also notable in figure 2 , shows that it collaborated intensively with institutions in the cluster where it belonged.

\subsection{Research output and impact at the document level}

For this study, a total of 1,715 documents were collected. These retrieved documents cited 39,789 documents. We traced the set of cited documents and analyzed the citation network lying in the both data sets, the retrieved set and the cited set, to discover the most popular and influential publication. On this citation network, a PageRank and single paper h-index were produced. PageRank is an approach to global impact analysis, whereas single paper h-index is an approach to local impact analysis. In this case, PageRank was used to analyze connections between documents within the whole citation network and a single paper h-index was used to examine a certain document and its citation network (Lee, 2011a).

PageRank is affected by the number of papers which have cited the original paper. By contrast, single paper h-index is strongly related to the number of papers which have cited the documents previously citing the original paper. The former case could be called as direct citation or $1^{\text {st }}$ generation of citation and the latter could be indirect citation or $2^{\text {nd }}$ generation of citation. As a result, a paper highly ranked by PageRank or citation frequency could be lowly placed by single paper h-index if the paper had small number of indirect citation.

According to our citation analysis, the most highly cited document since 2001 is Hirsch (2005), 'An index to quantify an individual's scientific research output.' PageRank also indicated that Hirsch's paper was the most influential. However, the single paper h-index identified Ingwersen's (1998) paper ‘The calculation of web impact factors' as the most influential.

According to PageRank, the top 10 documents were almost same as those derived according to citation 
〈Table 3〉 Top 10 documents in citation frequency

\begin{tabular}{l|c|c|c}
\hline \multicolumn{1}{c|}{ Document } & \multicolumn{3}{c}{ Rank } \\
\cline { 2 - 4 } & Citations & PageRank & h-index \\
\hline HIRSCH JE, 2005, An index to quantify an individual's scientific research output & 1 & 1 & 59 \\
\hline GARFIELD E, 1972, Citation analysis as a tool in journal evaluation & 2 & 2 & 37 \\
\hline GARFIELD E, 1955, Citation indexes for science & 3 & 3 & 28 \\
\hline $\begin{array}{l}\text { SEGLEN PO, 1997, Why the impact factor of journals should not be used for evaluating } \\
\text { research }\end{array}$ & 4 & 4 & 37 \\
\hline $\begin{array}{l}\text { WHITE HD, 1998, Visualizing a discipline: An author co-citation analysis of } \\
\text { information science }\end{array}$ & 5 & 5 & 19 \\
\hline $\begin{array}{l}\text { SMALL H, 1973, Co-citation in the scientific literature: A new measure of the } \\
\text { relationship between two documents }\end{array}$ & 5 & 10 & 10 \\
\hline $\begin{array}{l}\text { WHITE HD, 1981, Author co-citation: A literature measure of intellectual structure } \\
\text { MOED HF, 2005, Citation Analysis in Research Evaluation }\end{array}$ & 7 & 14 & 37 \\
\hline MACROBERTS MH, 1989, Problems of citation analysis: A critical review & 8 & 15 & 19 \\
\hline \begin{tabular}{l} 
INGWERSEN P, 1998, The calculation of web impact factors \\
\hline
\end{tabular}
\end{tabular}

〈Table 4〉 Top 10 documents by PageRank

\begin{tabular}{l|c|c|c}
\hline \multicolumn{1}{c|}{ Document } & \multicolumn{3}{c}{ Rank } \\
\cline { 2 - 4 } & PageRank & Citations & h-index \\
\hline HIRSCH JE, 2005, An index to quantify an individual's scientific research output & 1 & 1 & 59 \\
\hline GARFIELD E, 1972, Citation analysis as a tool in journal evaluation & 2 & 2 & 37 \\
\hline GARFIELD E, 1955, Citation indexes for science & 3 & 3 & 28 \\
\hline $\begin{array}{l}\text { SEGLEN PO, 1997, Why the impact factor of journals should not be used } \\
\text { for evaluating research }\end{array}$ & 4 & 4 & 37 \\
\hline $\begin{array}{l}\text { WHITE HD, 1998, Visualizing a discipline: An author co-citation analysis of } \\
\text { information science }\end{array}$ & 5 & 5 & 19 \\
\hline MOED HF, 2005, Citation Analysis in Research Evaluation & 6 & 8 & 59 \\
\hline GARFIELD E, 2006, The history and meaning of the Journal Impact Factor & 7 & 12 & 169 \\
\hline EGGHE L, 2006, Theory and practice of the g-index & 8 & 19 & 169 \\
\hline LOTKA AJ, 1926, The frequency distribution of scientific productivity & 9 & 17 & 37 \\
\hline $\begin{array}{l}\text { SMALL H, 1973, Co-citation in the scientific literature: A new measure of } \\
\text { the relationship between two documents }\end{array}$ & 10 & 5 & 10 \\
\hline
\end{tabular}

frequency. The top five documents were same according to both criteria and $70 \%$ of the top 10 documents were identical in both analyses.

When we identified the top 10 documents with a single paper h-index, there were 9 papers at the 10th place. To pick one of them as the tenth-ranking document, we used citation frequency. Of these nine papers, Small's (1973) was the most cited, which placed at the $10^{\text {th }}$ place. Nine of the top 10 documents were about Webometrics, as were half of the documents that were ranked $10^{\text {th }}$. It seems that a single paper h-index tends to discover a specific research 
〈Table 5〉 Top 10 documents in a single paper $\mathrm{h}$-index

\begin{tabular}{l|c|c|c}
\hline \multicolumn{1}{c|}{ Document } & \multicolumn{3}{c}{ Rank } \\
\cline { 2 - 4 } & h-index & Citations & PageRank \\
\hline INGWERSEN P, 1998, The calculation of web impact factors & 1 & 10 & 17 \\
\hline $\begin{array}{l}\text { ALMIND TC, 1997, Informetric analysis on the World Wide Web: A methodological } \\
\text { approach to webometrics }\end{array}$ & 2 & 11 & 16 \\
\hline CRONIN B, 1998, Invoked and the Web & 3 & 49 & 78 \\
\hline $\begin{array}{l}\text { EGGHE L, 2000, New informetric aspects of the Internet: Some reflections - many } \\
\text { problems }\end{array}$ & 3 & 63 & 81 \\
\hline $\begin{array}{l}\text { CRONIN B, 2001, Bibliometrics and beyond: Some thoughts on web-based citation } \\
\text { analysis }\end{array}$ & 3 & 18 & 37 \\
\hline $\begin{array}{l}\text { BJORNEBORN L, 2001, Perspectives of webometrics } \\
\text { BRIN S, 1998, The anatomy of a large scale hypertextual web search engine }\end{array}$ & 7 & 22 & 35 \\
\hline $\begin{array}{l}\text { THELWALL M, 2001, Extracting macroscopic information from Web links } \\
\text { THOMAS O, 2000, Webometric analysis of departments of librarianship and } \\
\text { information science }\end{array}$ & 7 & 65 & 25 \\
\hline $\begin{array}{l}\text { SMALL H, 1973, Co-citation in the scientific literature: A new measure of the } \\
\text { relationship between two documents }\end{array}$ & 10 & 5 & 10 \\
\hline
\end{tabular}

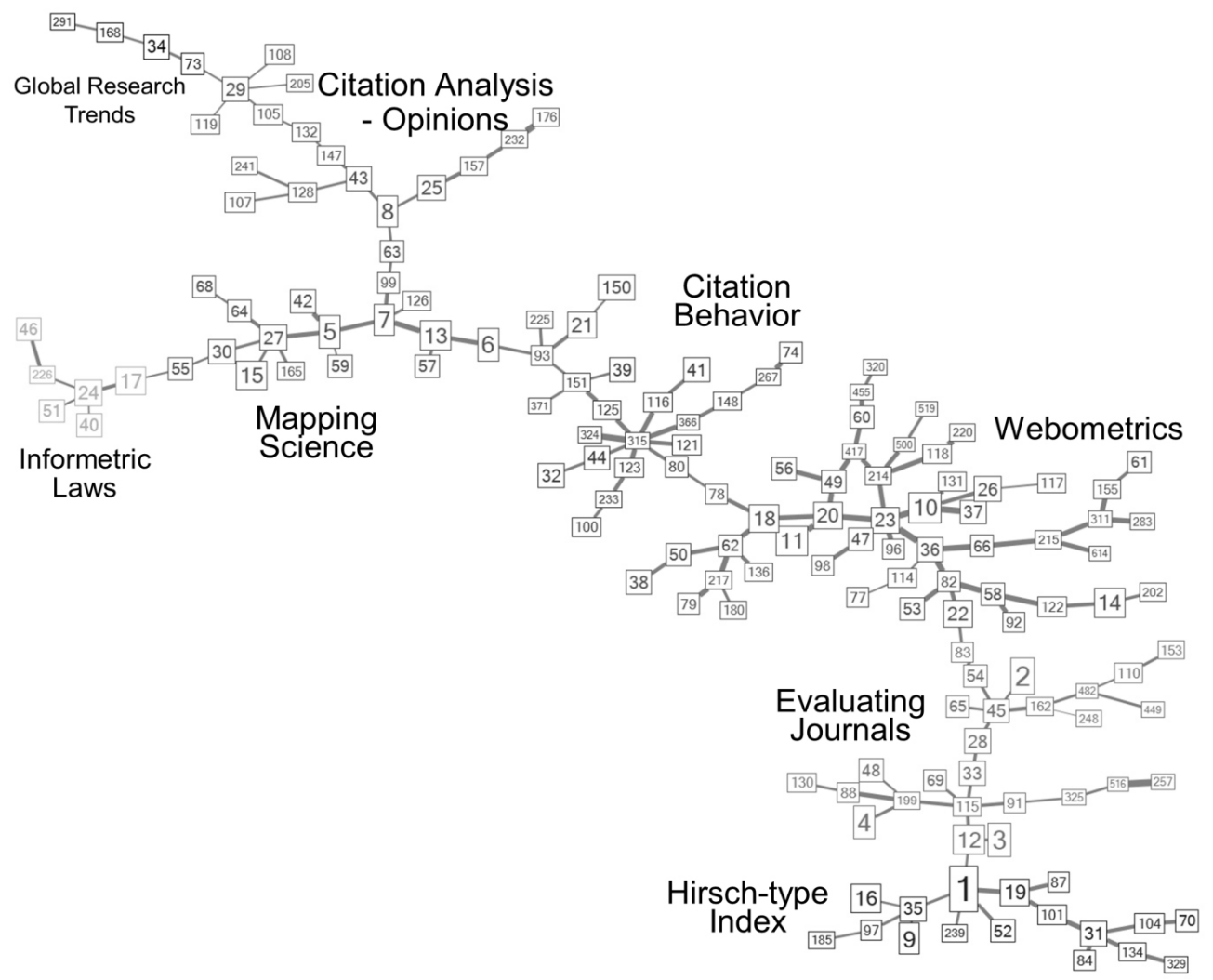

〈Figure 3〉 Pathfinder network of 158 core papers' co-citations 
area where researchers have conducted projects most actively. As a result, most of core papers identified by singe paper h-index belonged to the same research area.

In addition to the above results, we suggest that there are co-citation relationships among major publications that can be seen in Pathfinder network and PNNC clusters. The Pathfinder network in figure 3 illustrates eight clusters based on a co-citation network of 158 documents. We sorted out the top 100 list of each indicator and collected 158 papers without overlapped case. The topics of these eight clusters are: Evaluating journals, Citation analysis - Opinions, Webometrics, Citation behavior, Mapping science,
Hirsch-type index, Informetric laws, and Global research trends. The labels of clusters were entitled by two researchers reviewing the topics of documents in each cluster. These cluster labels show that since 2001, two key themes have developed within informetrics research: evaluative bibliometrics and webometrics. The core documents were selected by triangle betweenness centrality (TBC) (Lee, 2006c). We calculated TBC with the co-citation network of each cluster's documents to discover core document because TBC tended to indicate the core nodes that widely affected other nodes in the cluster. The core documents of each cluster are presented in table 6 .

〈Table 6〉 Top core papers in each cluster

\begin{tabular}{|c|c|c|}
\hline Cluster & Doc ID & Document \\
\hline \multirow{4}{*}{$\begin{array}{l}\text { Evaluating } \\
\text { journals }\end{array}$} & 4 & Seglen, 1997, Why the impact factor of journals should not be used for evaluating research \\
\hline & 45 & Glänzel, 2002, Journal impact measures in bibliometric research \\
\hline & 28 & Garfield, 1996, How can impact factors be improved? \\
\hline & 162 & Moed, 1995, Improving the accuracy of institute for scientific information's journal impact factors \\
\hline \multirow{4}{*}{$\begin{array}{l}\text { Citation } \\
\text { analysis - } \\
\text { Opinions }\end{array}$} & 25 & MacRoberts, 1996, Problems of citation analysis \\
\hline & 29 & $\begin{array}{l}\text { Moed, 1995, New bibliometric tools for the assessment of national research performance: Database } \\
\text { description, overview of indicators and first applications }\end{array}$ \\
\hline & 107 & $\begin{array}{l}\text { van Raan, 1996, Advanced bibliometric methods as quantitative core of peer review based } \\
\text { evaluation and foresight exercises }\end{array}$ \\
\hline & 128 & Narin, 1996, Bibliometric performance measures \\
\hline \multirow{4}{*}{ Webometrics } & 23 & Thelwall, 2001, Extracting macroscopic information from Web links \\
\hline & 10 & Ingwersen, 1998, The calculation of web impact factors \\
\hline & 18 & Cronin, 2001, Bibliometrics and beyond: Some thoughts on web-based citation analysis \\
\hline & 20 & Bjorneborn, 2001, Perspectives of webometrics \\
\hline \multirow{4}{*}{$\begin{array}{l}\text { Citation } \\
\text { behavior }\end{array}$} & 315 & $\begin{array}{l}\text { White, 1997-A qualitative study of citing behavior: Contributions, criteria, and metalevel } \\
\text { documentation concerns }\end{array}$ \\
\hline & 123 & Case, 2000, How can we investigate citation behavior? \\
\hline & 125 & Gilbert, 1977, Referencing as persuasion \\
\hline & 324 & Brooks, 1986, Evidence of complex citer motivations \\
\hline \multirow{4}{*}{$\begin{array}{l}\text { Mapping } \\
\text { science }\end{array}$} & 5 & $\begin{array}{l}\text { Small, 1973, Co-citation in the scientific literature: A new measure of the relationship between } \\
\text { two documents }\end{array}$ \\
\hline & 7 & White, 1981, Author cocitation: A literature measure of intellectual structure \\
\hline & 6 & White, 1998, Visualizing a discipline: An author co-citation analysis of information science \\
\hline & 13 & McCain, 1990, Mapping authors in intellectual space: A technical overview \\
\hline
\end{tabular}




\begin{tabular}{c|c|l}
\hline Cluster & Doc ID & \multicolumn{1}{c}{ Document } \\
\hline \multirow{4}{*}{$\begin{array}{c}\text { Hirsch-type } \\
\text { index }\end{array}$} & 1 & Hirsch, 2005, An index to quantify an individual's scientific research output \\
\cline { 2 - 3 } & 19 & Egghe, 2006, Theory and practise of the g-index \\
\cline { 2 - 3 } & 101 & $\begin{array}{l}\text { vanRaan, 2006, Comparison of the Hirsch-index with standard bibliometric indicators and with } \\
\text { peer judgment: for 147 chemistry research groups }\end{array}$ \\
\hline $\begin{array}{c}\text { Informetric } \\
\text { laws }\end{array}$ & 24 & Batista, 2006, Is it possible to compare researchers with different scientific interests? \\
\cline { 2 - 3 } $\begin{array}{c}\text { Global research } \\
\text { trends }\end{array}$ & 34 & Lotka, 1926, The frequency distribution of scientific productivity \\
\cline { 2 - 3 } & 168 & Khou, 2006, The emergence of China as a leading nation in science \\
\hline
\end{tabular}

\section{Conclusions}

This study endeavored to provide a comprehensive view of '-metrics' areas at several levels, nation, institution, and individual publication. Proceeding from what has been said above, the conclusion can be briefly stated as follows.

USA and England played key roles in the collaboration of metrics research as hub countries. As an emerging country of recent informetrics collaborations, China showed a notable collaboration pattern. It had intensively collaborated with selected few countries such as USA and Belgium.

In the aspect of institutions, Catholic University in Belgium and University of Amsterdam were hub institutions in Europe. In the collaboration network, the tendency of institutions' collaboration was discovered by several indicators. For example, Indiana University and the Office of Naval Research showed different collaboration tendency. Indiana University collaborated with many institutions, but the number of collaborations per institution was small. It result the discrepancy between ranking of the centrality criteria and the hs-index criteria. By contrast, the Office of Naval Research placed higher by the hs-index criteria than the centrality criteria because it had intensively collaborated with several particular institutions.

In addition, we found that some institutions played an important role to connect institution in different continents, which are University of Sussex and University of New South Wales. These institutions can be regarded as bridge institutions in the research collaboration network.

In the last decade, the most influential publication by an informetrics scientist is Hirsch's h-index paper and Ingwersen's web impact factor paper.

This study has also suggested various informetrics methods for domain analysis such as collaboration h-index and hs-index, PageRank, single paper h-index, Pathfinder network, and PNNC clusters. Because of the diversity of analytic methods employed, the results of this study contribute to the identification of major contributors from various informetrics perspectives. 


\section{References}

Brin, S., \& Page, L. (1998). The anatomy of a large-scale hypertextual Web search engine. Computer Networks and ISDN Systems, 30(1-7), 107-117. http://dx.doi.org/10.1016/S0169-7552(98)00110-X

Brookes, B. C. (1990). Biblio-, Sciento-, Infor-metrics??? What are we talking about?. In L. Egghe \& R. Rousseau (Eds.), Informetrics 89/90: Selection of papers submitted for the second international conference on bibliometrics, scientometrics and informetrics, Amsterdam (pp 31-43). Amsterdam: Elsevier.

De Nooy, W., Marvar, A., \& Batagelj, V. (2011). Exploratory social network analysis with Pajek (2nd ed.). New York: Cambridge University Press.

Garfield, E. E. (1955). Citation indexes for science: A new dimension in documentation through association of ideas. Science, 122(3159), 108-111.

Hood, W. W., \& Wilson, C. S. (2001). The literature of bibliometrics, scientometrics, and informetrics. Scientometrics, 52(2), 291-314.

Kim, H., \& Lee, J. Y. (2008). Exploring the emerging intellectual structure of archival studies using text mining: 2001-2004. Journal of Information Science, 34(3), 356-369.

http://dx.doi.org/10.1177/0165551507086260

Lee, J. Y. (2006a). Some improvements on h-index: Measuring research outputs by citations. Journal of the Korean Society for Information Management, 23(3), 167-186.

http://dx.doi.org/10.3743/KOSIM.2006.23.3.167

Lee, J. Y. (2006b). A novel clustering method for examining and analyzing the intellectual structure of a scholarly field. Journal of the Korean Society for Information Management, 23(4), 215-231. http://dx.doi.org/10.3743/KOSIM.2006.23.4.215

Lee, J. Y. (2006c). Centrality measures for bibliometric network analysis. Journal of the Korean Society for Library and Information Science, 40(3), 191-214. http://dx.doi.org/10.4275/KSLIS.2006.40.3.191

Lee, J. Y. (2010). A bibliometric analysis on LED research trends. Korea Institute for Advancement of Technology (KIAT).

Lee, J. Y. (2011a). A study on document citation indicators based on citation network analysis. Journal of the Korean Society for Library and Information Science, 45(2), 119-143. http://dx.doi.org/10.4275/KSLIS.2011.45.2.119

Lee, J. Y. (2011b). WNET. (Version 0.4) (Software).

Lee, J. Y., \& Choi, S. H. (2011). Intellectual structure and infrastructure of informetrics: Domain analysis 
from 2001 to 2010. Journal of the Korean Society for Information Management, 28(2), 11-36. http://dx.doi.org/10.3743/KOSIM.2011.28.2.011

Schubert, A. (2009). Using the h-index for assessing single publications. Scientometrics, 78(3), 559-565. http://dx.doi.org/10.1007/s11192-008-2208-3

Wouters, P. (1999). The citation culture. Unpublished doctoral dissertation, University of Amsterdam, Amsterdam. Retrieved from http://garfield.library.upenn.edu/wouters/wouters.pdf 